\title{
Challenges Facing Financial Inclusion Due to the COVID-19 Pandemic
}

\section{Tea Kasradze}

Caucasus International University

\section{Abstract}

Financial inclusion is often considered as an access to financial resources for the wide public and small and medium-sized businesses, although it is a much broader concept and includes a wide range of access to quality financial products and services, including loans, deposit services, insurance, pensions and payment systems. Mechanisms for protecting the rights of consumers of financial products and services are also considered to be subject to financial inclusion. Financial inclusion acquires great importance during the pandemic and post-pandemic period. The economic crisis caused by the pandemic is particularly painful for low-income vulnerable population. A large part of the poor population who were working informally has lost source of income due to lockdown from the pandemic. Remittances have also been reduced / minimized, as the remitters had also lost jobs and are unable to send money home. Today, when people die from Coronavirus disease, it may be awkward to talk about the financial side of a pandemic, but the financial consequences can be far-reaching if steps are not taken today to ensure access to and inclusion of financial resources. The paper examines the impact of the pandemic on financial inclusion and the responses of the governments and the financial sectors to the challenge of ensuring the financial inclusion of the poor population and small and medium enterprises.

Keywords: financial inclusion, economic growth, access to financial products and services, pandemic, low-income population

\section{Introduction}

The economic growth rate in Georgia in 2019-2020 was one of the highest among the Eastern European countries and the Caucasus region - 5.1\%. However, talking about this issue in a positive context by experts and government officials causes a negative attitude from citizens for some reason. We often hear not even a rhetorical question can a country have one of the highest GDP growth rates in the region and the population cannot feel it? The answer is simple - it is possible and we should search for the reason in the non-inclusive growth of the economy (Kasradze \& Zarnadze, 
2019). Inclusion is an important factor for the sustainable development of the economy (Kasradze, Tea, 2018). The cause of poverty of the population is unequal opportunities, which means not only unequal incomes, but also unequal access to economic opportunities.

Inclusive development benefits the wide society and not just individuals within a narrow group of society. Inclusion makes it possible to derive not only quantitative but also qualitative effects from economic growth (Kasradze, Tea; Zarnadze, Nino, 2018).

The term "inclusion" first appeared in the Socio-Economic Development Strategy of Georgia "Georgia 2020", where we read that "Our main goal is to benefit a significant part of the population of Georgia from the goodness brought by inclusive or universal economic growth" and the development of work force focused on the requirements of the labor market, the improvement of the social security system and the provision of a quality and affordable health care system are considered by the government as the main way to achieve this goal (Government of Georgia, 2014).

Financial inclusion is an integral part of economic inclusion. Moreover, the path to inclusive growth and development of the economy goes through financial inclusion. It is true that among the United Nations' 17 Sustainable Development Goals (SDGs), which should be achieved by humanity through joint efforts by 2030, we do not find financial inclusion, but achieving many of these goals (GOAL 1: No Poverty; GOAL 2: Zero Hunger; GOAL 3: Good Health and Well-being; GOAL 4: Quality Education; GOAL 5: Gender Equality; GOAL 8: Decent Work and Economic Growth; GOAL 10: Reduced Inequality) would be impossible without financial inclusion (United Nations, 2015). UN member states use the Global Financial Inclusion (Global Findex) database to measure progress towards sustainable development goals. This document is also the statistical information base for our paper.

The issue of growing financial inclusion gained a special significance during the COVID-19 pandemic, when a large part of the world's population was locked up at home. According to a preliminary assessment by the International Labor Organization (ILO), 25 million people lost their jobs and livelihoods (ILO, 2020). Now is the time for governments and financial institutions to play their part in providing greater access to financial services for poor individuals and households as soon as possible during the crisis. Governments, working together with financial institutions, must first and foremost be able to provide financial access to poor individuals and households with the necessary support to ensure their survival in these times (Ozili, 2020) (Tarek Eldomiaty, 2020).

Often financial inclusion refers to the availability of only financial resources for the broad layers of society and small and medium-sized businesses, although it is a far more common concept and includes a wide range of quality financial products and services, including loans, deposit services, insurance, pensions and payment systems. 
As well as financial education and consumer protection mechanisms (Giovanna Prialé Reyes, 2010).

Financial inclusion implies equality of access to financial information and services. Every member of the public should have access to the financial information and services that the other part of the population enjoys. Yet, unfortunately, in today's reality billions of poor people do not have access to numerous financial globali and non-financial products and services (Kasradze, Financial Globalisation-Positive and Negative Impacts on Developing Countries, 2014). Financial inclusion allows poor people to finance their own businesses, save, contribute to the well-being of their own families, and protect themselves from daily risks. The readiness of the country's financial sector as a whole, as well as the responsible and social approach of specific financial institutions - microfinance organizations, insurance companies, banks and others - play a big role in increasing financial inclusion in general in conjunction with public policy. It is important these institutions to be well aware of their role in struggling against poverty by promoting financial inclusion (Kasradze, Poverty - A Global Socio-Economic Problem, 2013).

The following definition of financial inclusion is also found - financial inclusion includes a diverse range of financial and non-financial products and services to combat financial exclusion. In developing countries, financial exclusion usually means being without access to a bank account in particular. This category of the population is called the unbanked category. Bank accounts allow people to save money and make (send and receive) payments. Lack of access can be caused by various reasons, such as lack of financial knowledge (Tea Kasradze, Vakhtang Antia, Ekaterine Gulua, 2019), (Nino Zarnadze, 2019), distrust of financial institutions in general, high banking fees and rates, territorial distance from bank customers, etc. In developed countries, we are dealing with more the so-called underbanked challenges, which is caused by the high cost of financial products and services due to risk management measures taken by banks.

The World Bank defines financial inclusion as access to and use of formal financial services, and believes that it is a global problem and that the authorities should pay significant attention to its improvement in the country's economic development strategy (The World Bank, 2018). According to the World Bank Global Findex Database 515 million adults worldwide opened an account at a financial institution or through a mobile money provider between 2014 and 2017. Which means that by $2017,69 \%$ of the adult population had an account, while in 2014 this figure was $62 \%$ and in 2011 it was 51\%. 94\% of adults in high-income economies have an account; $63 \%$ - in developing economies.

Globally, 1.7 billion adults lack an account in 2017. In the Global Findex survey conducted by the World Bank in 2017, the majority (2/3) named the lack of need for an account due to lack of funds as the reason for not having an account. A quarter cite the distance and fees of banking institutions as the reason. Approximately the same 
number cite the fact that other family members have an account as the reason for not having an account. 1/5 cited a lack of documents and distrust of the financial system, while 6\% cited a religion. (Asli Demirgüç-Kunt, Leora Klapper, Dorothe Singer, Saniya Ansar, Jake Hess, 2018).

Having an account is an important first step towards financial inclusion. However, a real inclusion requires the ability to use these accounts securely and conveniently (digital payments, payments via a mobile phone or the internet) (Dorofeiev, 2019). The Global Findex database provides information not only about who owns the account, but also whether people use these accounts for payments. 1/5 of the account holders state that they have not put or withdrawn money from their accounts in the last 12 months, which is why these accounts are considered inactive and naturally such accounts cannot be considered as promoting financial inclusion. In countries where more than $80 \%$ of the population use an account, private sector initiatives and innovations have played a major role, including the main impetus for low rates on account usage and the ability to make mobile phone transfers.

\section{Financial Inclusion in Georgia}

According to the Inclusive Development Index (IDI) 2018 of the World Economic Forum Report, Georgia ranks 32nd among 74 developing countries in the world with a 3.991 inclusive development index, lagging behind post-Soviet countries (Diagram 1). The Inclusive Development Index (IDI) is an annual assessment of 103 countries' economic performance that measures how countries perform on eleven dimensions of economic progress in addition to GDP. It has 3 pillars; growth and development; inclusion and; intergenerational equity - sustainable stewardship of natural and financial resources (World Economic Forum, 2018).

Diagram 1. The Inclusive Development Index (IDI)

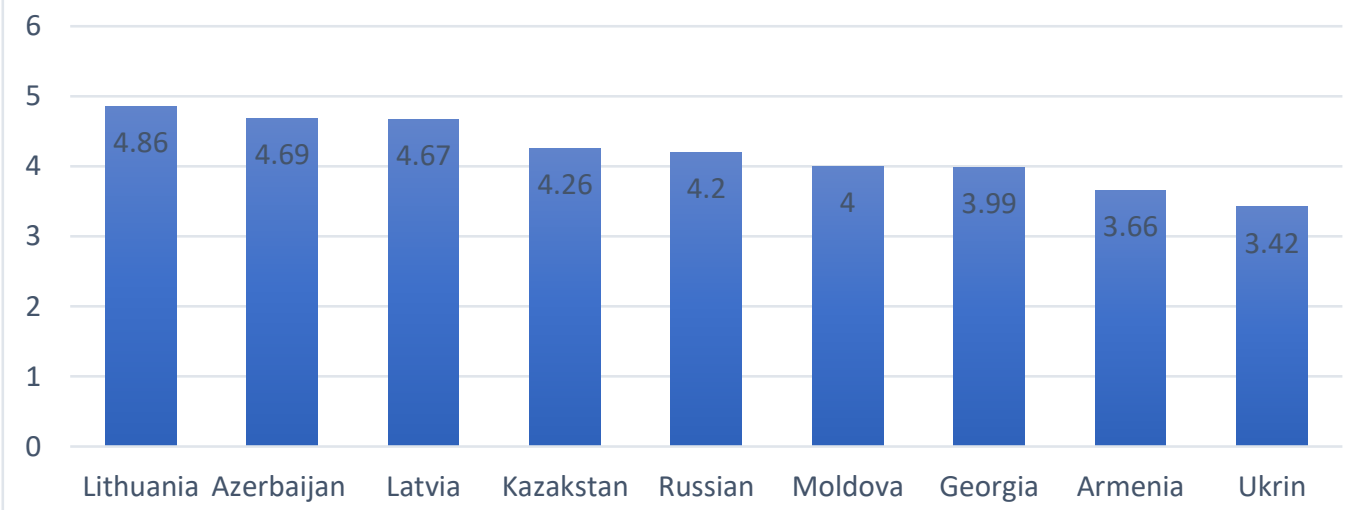

${ }^{1}$ IDI scores are based on a 1-7 scale: $1=$ worst and $7=$ best 
Source: http://www3.weforum.org/docs/WEF_Forum_IncGrwth_2018.pdf

Special scrutiny is required for the part on financial intermediation, which ranks Georgia on 16th place among low and mid income states. Georgia is on the 31st place among states with the access to business accounts for the poorest $40 \%$ of the population. In terms of access to credit, it ranks 23rd. Georgia is in the middle in terms of accessibility of financial sector. The situation is even worse in case of financial intermediation of real economy investment (19/38). In terms of accessibility of local asset market, Georgia takes 34th place among 38 low and middle income states, as for attracting venture capital, Georgia is on 32nd place (Arevadze, 2015).

As mentioned above, even well-developed financial systems today have failed to achieve comprehensiveness and certain segments of the population remain outside the official financial systems. As a result, in recent years, the importance of an inclusive financial system has been widely recognized in political circles, and financial inclusion is considered a policy priority in many countries, including Georgia. An inclusive financial system facilitates the efficient allocation of financial resources and thus reduces the value of capital. (Kasradze, The Major Policies Used by the Governments of Developing Countries for Attracting Direct Investments, 2014) In addition, access to financial resources and services can significantly improve a dayto-day financial management, facilitate to reduce the use of high-risk informal credit sources.

According to the World Bank surveys conducted in 2011, 2014 and 2017, the growth of financial inclusion in Georgia is visible in all directions. According to the World Bank Global Findex database, in 2017, 61\% of the adult population of Georgia (15 years and older) had accounts, while in 2011 and 2014 this figure was $32.98 \%$ and 39.66\%, respectively (Asli Demirgüç-Kunt, Leora Klapper, Dorothe Singer, Saniya Ansar, Jake Hess, 2018).

According to the same study, in 2017, the adult population of Georgia without accounts named the following reasons for not having accounts:

Table 1.

\begin{tabular}{|l|l|}
\hline Reason & $\%$, age $15+$ \\
\hline No account because financial institutions are too far away & 2.55131602 \\
\hline No account because financial services are too expensive & 12.7379675 \\
\hline No account because of insufficient funds & 24.0508652 \\
\hline No account because of lack of necessary documentation & 16.8846092 \\
\hline No account because of lack of trust in financial institutions & 9.13279533 \\
\hline No account because of no need for financial services ONLY & 0.92726338 \\
\hline No account because of religious reasons & 1.17684305 \\
\hline No account because someone in the family has an account & 15.6534386 \\
\hline
\end{tabular}


It is complimentary that the number of account holders in Georgia is growing from year to year, but in terms of financial inclusion, it is more important how many other financial products and services are available to them, how much access they have to financial technology. The most significant driver of financial inclusion today is technology. Its potent effect is its ability to deliver financial services to people wherever they are and when they need them. Financial inclusion has arisen as a byproduct of these technologies now commonly known as FinTech. Since financial technology lowers the costs of financial intermediation, it enables profitable intermediation of the unbanked poor (Ashenafi Beyene Fanta, 2019). Financial technologies have a special load during COVID-19. Fintech allows users locked at home due to COVID-19 to transfer money from any bank account, make payments and services for trade and business in any part of the country and abroad. Financial technology can also create a framework for the inclusion and use of technological capabilities to facilitate transaction execution, access and use of accounts.

According to the Global Financial Inclusion (Global Findex) database, in 2014 and 2017, $13.37 \%$ and $29.07 \%$ of the adult population made digital payments respectively, while $20.82 \%$ and $52.95 \%$, respectively, made or received digital payments which is quite a low indicator. The trust of poor individuals and families towards the Fintech platforms is of particular importance during COVID-19 pandemic. Fintech businesses need more transparency and security. Increasing transparency alone will not build trust. A combination of ethics, regulation, oversight, communication and transparency will be key elements of trust that will enable people to benefit from Fintech business services on the one hand, and Fintech companies to provide financial services to the poor and families on the other.

The financial industry constantly offers innovative products and services to the population, thereby reaping great benefits itself. The appearance of Fintech companies on the Georgian financial market and their active activities have significantly contributed to solving the problem of gaining access to financial services by offering the services needed by individuals and organizations at a reasonable cost. Fintech can help millions of unbanked and underbanked individuals improve their financial well-being and tackle poverty.

Fintech has boosted digital, crowdfunding, and peer-to-peer (P2P) cashless transactions in recent years. P2P loans have proved to be particularly profitable for people in emerging markets who are unable to take loans from traditional financial institutions because they do not have a financial or credit history that would allow them to assess their credibility.

According to a World Bank study, there has been an increase in access to credit in recent years. In particular, according to the data of $2017,44.92 \%$ of the adult population had access to any kind of loan in Georgia during the last year (Borrowed any money in the past year), while the similar figure in 2014 was $36.65 \%$. It is true 
that $8 \%$ growth in 3 years is not a bad indicator, but if we look at the statistics of access to credit in other countries, even the former Soviet countries, we will see that the situation is not so favorable (Diagram 2):

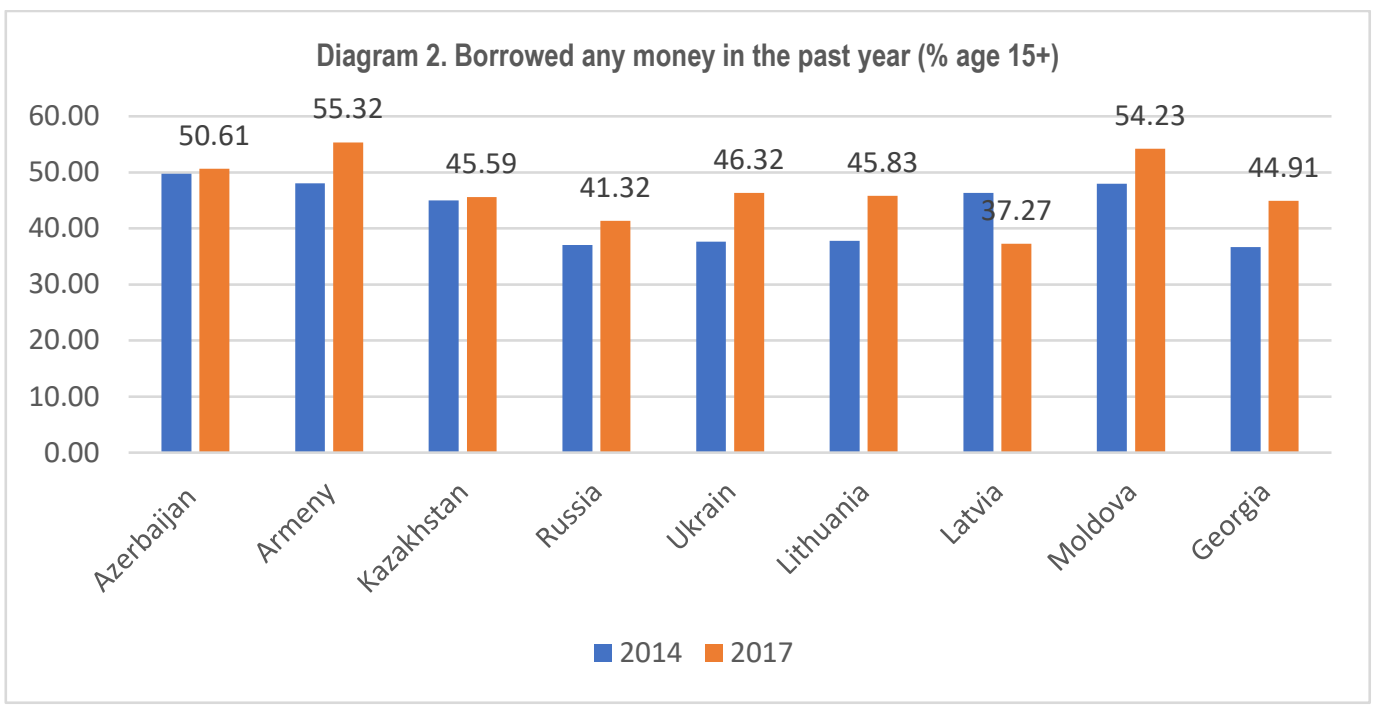

However, it should be noted that only $23.65 \%$ of the adult population borrowed in 2017 , compared to $13.86 \%$ in 2014 , while $20.33 \%$ of the adult population borrowed from financial institutions or used a credit card in 2014, and $27.44 \%$ in 2017 . Which, on the one hand, indicates that a small part of the adult population has access to credit cards and, on the other hand, all in all a small part of the population has taken loans from financial institutions. If you look at other sources of credit, such as borrowed from family or friends, unfortunately, we have a growth tendency here as well. In 2011-2014-2017, these figures were $14.01 \%, 16.23 \%$ and $20.68 \%$, respectively, indicating that official loans are either not available for some reason or due to high interest rates, people choose this path.

With that being said, it is thought-provoking that a very small portion of the adult population borrowed to start or expand a business. In particular, in 2014 and 2017 $2.71 \%$ and $3.07 \%$ borrowed to start, operate, or expand a farm or business. The similar figures in the former Soviet Union look like this (Diagram 3): 


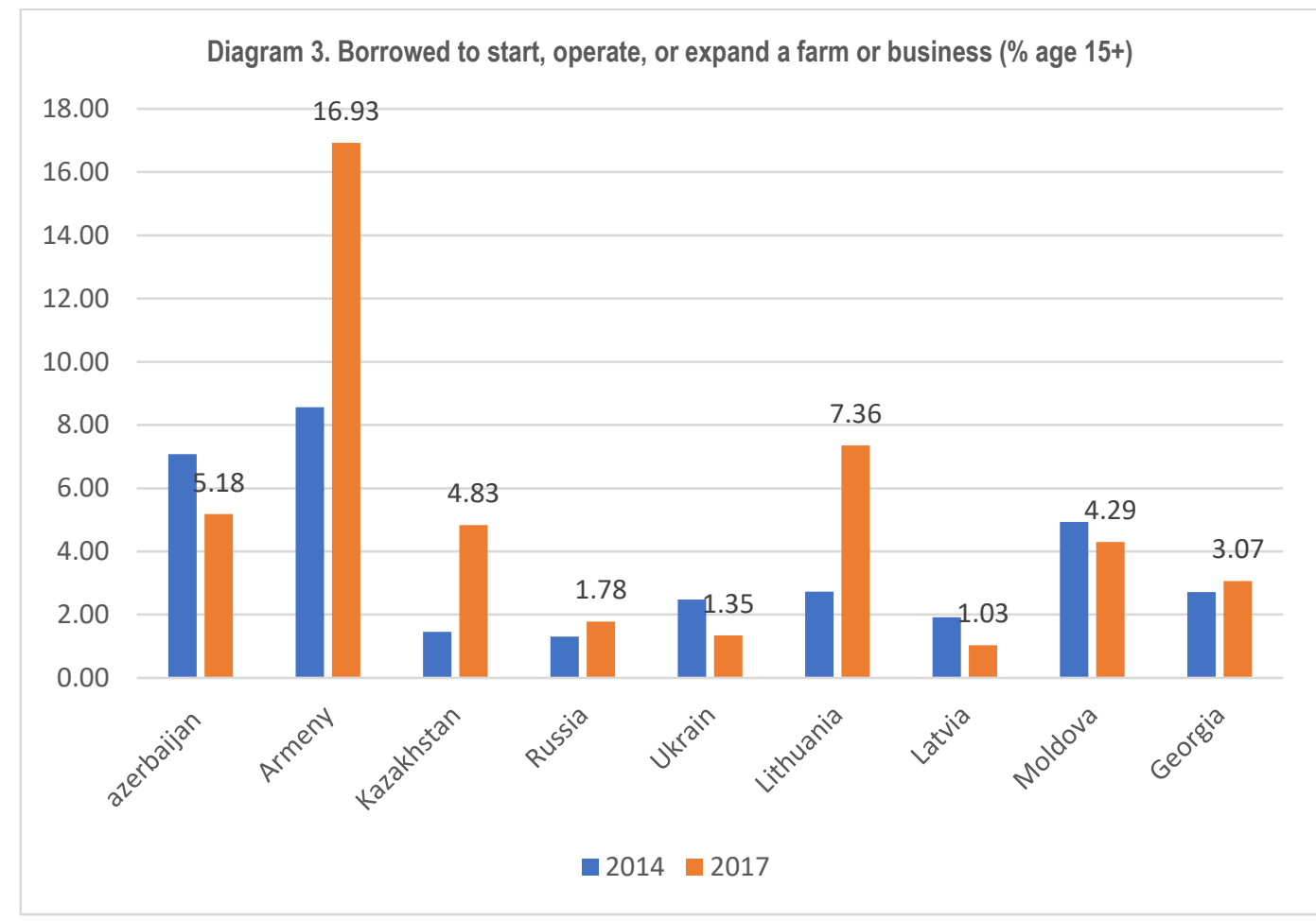

The COVID-19 crisis has once again shown how important digital funding is for the poor in difficult socio-economic conditions. In many developing countries of the world, including Georgia, remittances received from migrants abroad using international digital payment systems are a means of livelihood for many poor families. Sending remittances using mobile devices is an effective tool towards financial inclusion. The pandemic has caused a double problem with remittances in developing countries, one- Remittances have been sharply reduced, as the remitters had also lost jobs and are unable to send money home, which negatively affected both the well-being of specific individuals and families and the country's economy as a whole. Second - the lack of skills to make and receive digital payments in the population. Digital financial services, on the one hand, need encouragement from the regulator, and on the other hand, in parallel with the promotion of these services and raising public awareness, it is desirable to reduce tariffs on digital services. Reduced tariffs will encourage and increase the number of entities using digital services.

According to the World Bank Find Global Findex Database 2014 and 2017 data, digital payments were made by $13.37 \%$ and $20.07 \%$ of the adult population in the last one year, respectively. While digital payments were made and received by $20.82 \%$ and $52.95 \%$ of the adult population, respectively. If we look at the statistics of developed European countries (Diagram 4), the difference is very big and it is clear that the 
Georgian government and the financial sector have a lot of joint work to do in this direction.

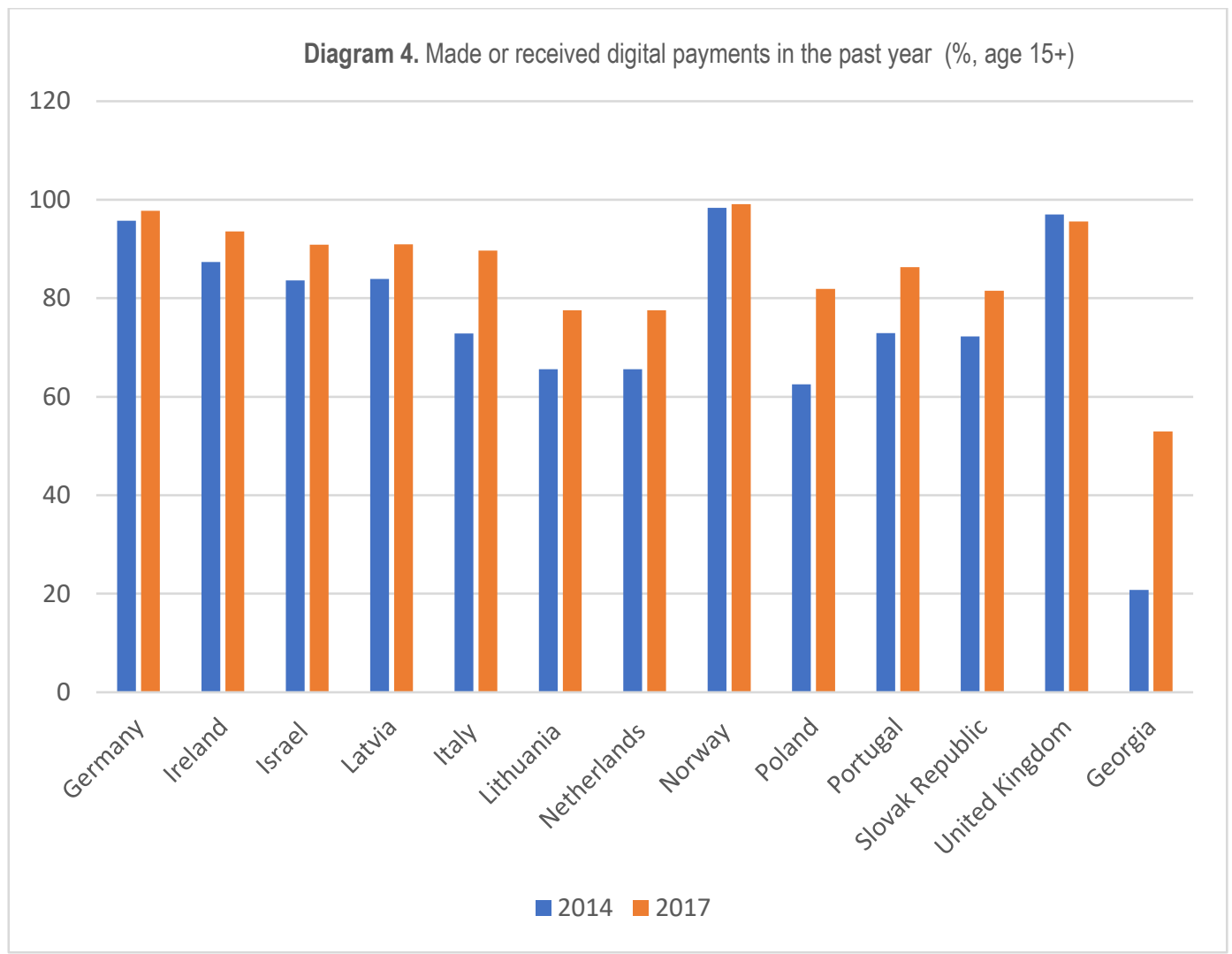

During the COVID-19 pandemic, a number of cases of human infection with the virus caused by touching money were reported in Georgia. Naturally, using non-cash in such a situation is one of the best ways to protect yourself. In the report on the measures taken by the Government of Georgia against COVID-19, we read that the banking sector of Georgia is one of the leaders in the world in terms of payment technologies. There are quite a variety of means of payment and banking services: contactless cards, mobile wallets, payment bracelets, barcodes, internet banking, mobile banking, telephone banking, etc. The services can be used without physical contact with cash. In addition to the fact that these services are usually more convenient, their usage is especially important now when social distance is so critically important. We call on the population to use Internet payment services as much as possible in order for the country to be able to fight the virus effectively (Government of Georgia, 2020).

However, the fact that in 2017 only $18.52 \%$ of the adult population used a debit or credit card to make a purchase in the past year and $15.27 \%$ used a mobile phone or 
the internet to access an account (\% with an account, age 15+) indicates that on the one hand a large part of the adult population does not have accounts and, therefore, neither debit and credit cards, on the other hand, those who do have preference for cash transactions. In 2011-2014-2017, the percentage of the adult population in Georgia, according to the possession of debit and credit cards, looks like this (Diagram $5)$.

Diagram $5 . \%$ of adult population (age $15+$ )

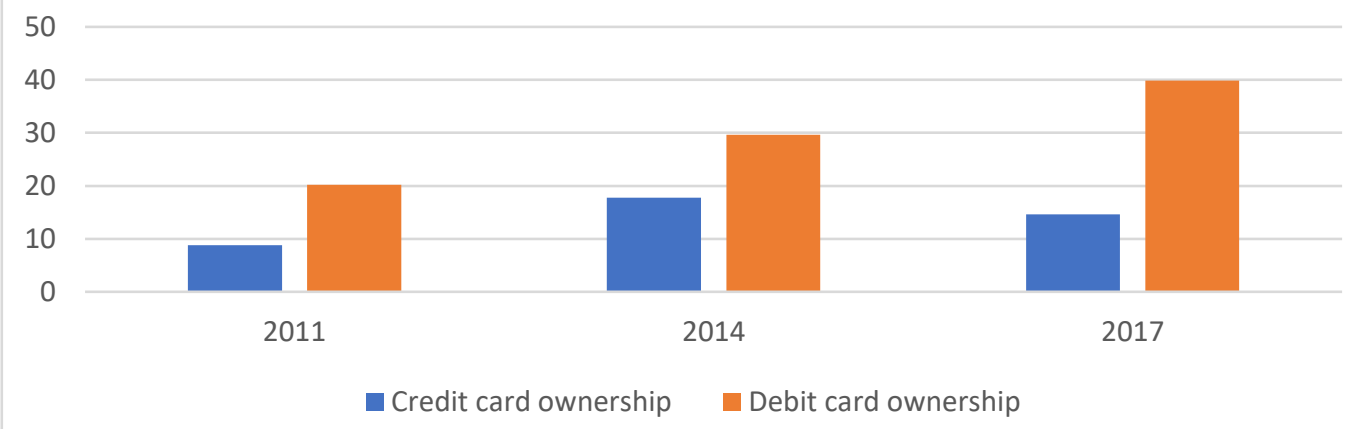

The growth tendency of debit card holders is complimentary, but the declining number of credit card holders in 2017 compared to 2014 still indicates the problem of access to credit and the preference for loans by non-financial institutions by a large part of the population, which does not really help increase financial inclusion.

It should also be noted that a large part of the population was left without livelihoods during the COVID-19 pandemic in Georgia. According to research, a large part of the adult population (44.84\%) does not have access to emergency funds, which indicates low financial inclusion and complicates the situation of the already poor population in a pandemic. In 2017, there was a decrease in access to emergency funds compared to 2014. In particular, the percentage of the adult population that can access to emergency funds has decreased from $45.51 \%$ to $41.24 \%$. In addition, for $18.18 \%$ of the adult population, a loan from a bank, an employer, or a private lender is the main source for emergency funds; And unfortunately for only 5.48\% - savings. This means that despite the joint monetary and anti-crisis measures taken by the government and the National Bank during the pandemic, access to financial resources for a large part of the population will still be one of the main problems of financial inclusion in the near future (Kasradze, Theoretical Aspects of Financial Crises, 2015).

\section{Conclusion}

COVID-19 is not just a pandemic that has affected nearly 14 million people to date and has taken the lives of up to 600,000 people worldwide. It is a global economic crisis triggered by lockdown measures taken to stop the virus. It is a global macroeconomic shock of uncertain scale and duration that has left people without jobs, food, 
education (even temporarily). The movement of capital has been halted due to risk aversion by investors and other stakeholders (Kasradze, Investment Environment in Georgia and and Domestic Investment Potential of the Country, 2014). Due to the pandemic, on the one hand, the amount of debts of citizens already in debt has increased even more, and on the other hand, the financial systems themselves are under stress. Financial institutions are unable to receive disbursements from their clients whose livelihoods have been destroyed by the pandemic (Arunachalam \& Crentsil, 2020)

Since the COVID-19 pandemic has had a negative impact on the financial sector, naturally the same can be said about financial inclusion. The pandemic affected all stakeholders in financial inclusion - the poor, microfinance organizatins, banks and other financial institutions. Under the anti-crisis plan developed by the government, initially citizens were given the opportunity to defer loan repayment for 3 months with the help of the state in order to avoid problems with the payment and the corresponding fines. After the expiration of the term, the loan payment was postponed for another 3 months. The anti-crisis plan also provides direct financial assistance to citizens who have lost their jobs or been on unpaid leave, as well as to various categories of vulnerable groups.

The National Bank of Georgia has taken significant measures to mitigate the negative impact on financial sector by COVID-19 and to stimulate the country's economy. In particular (Georgia, 2020):

- Reduced existing capital and liquidity requirements, allowing the banking sector to offset potential losses through these buffers and being able to continue normal business operations and crediting the real economy;

- In order to provide liquidity to the banking system, the National Bank has launched swap operations, thus supplying the system with GEL liquidity. The purpose of these operations is to reduce liquidity risk in the system so that liquidity risk does not become an impediment to crediting the economy. The $\$ 200$ million swap instrument will be distributed among banks in proportion to their market share;

- Considering the role of microfinance organizations in providing financial services to businesses and the population of the regions of Georgia, the National Bank provides liquidity support to microfinance organizations through \$200 million in swap operations;

- Commercial banks' capital requirements have been eased, which will free up 1.6 billion GEL in capital for the banking sector, which could be used to offset potential losses or to lend 16 billion GEL to the economy.

The mentioned anti-crisis measures ensure the survival of stakeholders of financial inclusion in the short term, but their long-term survival is important also. The question naturally arises - how long can the moratorium on payments be extended? 
Where will customers get the money to repay the loan? On what basis will citizens and small businesses be able to take out new loans and on what basis will financial institutions issue new loans? Who will get the final blow when the large-scale loan defaults start? The danger is real, and the questions remain unanswered.

Although COVID-19 in terms of access to financial resources threatened the positive trends discussed above in the paper on financial inclusion, in some respects it could also be said to have had a positive effect. In particular, due to the high risk of spreading the virus:

Remote service was encouraged (POS cashing, remote identification, etc.); A new rule has been developed and approved, which allows customers to withdraw money from POS terminals of shopping facilities (pharmacy, grocery store) in addition to ATMs; The National Bank of Georgia has started issuing permits to banks on remote customer identification procedures. At this stage, three banks were allowed to agree to use remote identification for different product purposes; Some products and financial technology companies are being communicated on the digital transformation of some products; Remote lending procedures have been simplified according to which temporarily no real estate appraisal is required on the spot. Demand for renewal of financial statements was eased, etc. We think that all this will have a stimulating effect on financial inclusion in the future.

\section{Bibliography}

[1] Arevadze, L. (2015, December 15). What is Inclusive Growth? IDFI Publications.

[2] Arunachalam, R. S., \& Crentsil, G. L. (2020). Financial Inclusion in the Era of COVID-19. An Online Participative Conference For Central Bankers, Ministries of Finance, Financial Sector Development \& Financial Inclusion Professionals, Commercial \& Microfinance Bankers, NBFIs, DFIs, MFIs, Consultants, FINTECH \& RegTech Companies, Investors, Ins. THE FINANCIAL INCLUSION ADVOCACY CENTRE.

[3] Ashenafi Beyene Fanta, D. M. (2019). The Relationship Between Technology and Financial Inclusion. In D. M. Ashenafi Beyene Fanta, Extending Financial Inclusion in Africa (pp. 211-230). Elsevier Inc.

[4] Asli Demirgüç-Kunt, Leora Klapper, Dorothe Singer, Saniya Ansar, Jake Hess. (2018). The Global Findex Database 2017 - Measuring Financial Inclusion and the Fintech Revolution. Washington, DC: International Bank for Reconstruction and Development/The World Bank.

[5] Dorofeiev, S. N. (2019). Digital financial inclusion: evidence from Ukraine. Investment Management and Financial Innovations, 194-205.

[6] Giovanna Prialé Reyes, L. D. (2010). FINANCIAL INCLUSION INDICATORS FOR DEVELOPING COUNTRIES:The Peruvian Case. DOCPLAYER. Retrieved from https://docplayer.net/20698246-Financial-inclusion-indicators-fordeveloping-countries-the-peruvian-case.html 
[7] Government of Georgia. (2014). Social-economic Development Strategy of Georgia "GEORGIA 2020". Tbilisi: Legislative Herald.

[8] Government of Georgia. (2020). Report on the measures taken by the Government of Georgia against COVID-19. http://gov.ge/files/76338_76338_444796_COVID-19angarishi...pdf

[9] Kasradze, T. (2013). Poverty - A Global Socio-Economic Problem. Caucasus International University HERALD \#5, pp. 15-18.

[10] Kasradze, T. (2014). Financial Globalisation-Positive and Negative Impacts on Developing Countries. International Scientific-Analytical Journal Ekonomisti.

[11] Kasradze, T. (2014). Investment Environment in Georgia and and Domestic Investment Potential of the Country. International Scientific-Analytical Journal Ekonomisti.

[12] Kasradze, T. (2014). The Major Policies Used by the Governments of Developing Countries for Attracting Direct Investments. Caucasus International University HERALD.

[13] 13.Kasradze, T. (2015). Theoretical Aspects of Financial Crises. Proceedings of Materials of International Scientific-Practical Conference ACTUAL PROBLEMS OF SUSTAINABLE DEVELOPMENT OF NATIONAL ECONOMIES (pg. 335-337). Tbilisi: PUBLISHING HOUSE OF PAATA GUGUSHVILI INSTITUTE OF ECONOMICS OF IVANE JAVAKHISHVILI TBILISI STATE UNIVERSITY.

http://www.pgie.tsu.ge/contentimage/konferenciebi/2015_pdf

[14] Kasradze, T., \& Zarnadze, N. (2019). CHALLENGES OF ECONOMIC OF GEORGIA: GOOD AND BAD ECONOMIC GROWTH. European Journal of Economics and Business Studies, 178-186.

[15] Kasradze, Tea. (2018). Trends of Financing for Development in Georgia. American Scientific Journal \#21 ,32-40.

[16] Kasradze, Tea; Zarnadze, Nino. (2018, May). Enhancing Workforce Competitiveness through Improving Quality of Education - An Indispensable Means for Overcoming Poverty. International Journal of Innovative Technologies in Economy, pp. 19-21.

[17] Nino Zarnadze, T. K. (2019). A WEAK EDUCATION SYSTEM-A CHALLENGE FOR SOCIETY'S WELL-BEING. Journal of Teaching and Education,, 137-149.

[18] Ozili, P. K. (2020). Financial Inclusion and Fintech during COVID-19 Crisis: Policy Solutions. SSRN Electronic Journal. doi:10.2139/ssrn.3585662

[19] Tarek Eldomiaty, R. H. (2020). Institutional determinants offinancial inclusion: evidence from world economies. International Journal of Development Issues.

[20] Tea Kasradze, Vakhtang Antia, Ekaterine Gulua. (2019). Challenges of Financial Management of the Higher Education Institutions in Georgia. European Journal of Economics and Business Studies, 187-206. 
[21] The World Bank. (2018). UFA2020 Overview: Universal Financial Access by 2020. The World Bank. Retrieved from https://ufa.worldbank.org/

[22] United Nations. (2015). TRANSFORMING OUR WORLD: THE 2030 AGENDA FOR SUSTAINABLE DEVELOPMENT. United Nations.

[23] World Economic Forum. (2018). The Inclusive Development Index 2018 Summary and Data Highlights. 